\title{
(No) recourse to lunch: a frontline view of free school meals and immigration control during the Covid-19 pandemic
}

At the height of the UK's Covid-19 'lockdown', a group of families subject to the 'no recourse to public funds' (NRPF) immigration condition brought legal action against the British government on the basis of their exclusion from free school meals support. The challenge succeeded, resulting in the temporary extension of free school meals support to some families with NRPF during the coronavirus pandemic. According to the Home Office, the extension was put in place, 'in recognition of the difficulties they may be facing during these unique circumstances' (Home Office, 2020). The need was thus framed as something exceptional, induced by the Covid-19 crisis.

While the pandemic has exacerbated the issues faced by those with NRPF, families subject to the immigration condition have long been living in extreme poverty and precarity. The UK government's line ignores the longstanding destitution experienced by migrant families with NRPF and the years of campaigning by activist groups and NGOs for their access to free school meals. The extension of eligibility for free school meals may be limited to the coronavirus outbreak, but the hardship experienced by families with NRPF is not. The Covid-19 pandemic has made more visible the everyday destitution experienced by these families, which has been largely hidden from view.

\section{The no recourse to public funds crisis}

NRPF is a restriction imposed on people 'subject to immigration control'. It prohibits access to most mainstream welfare benefits and statutory homelessness assistance. People with NRPF are also unable to access support and services that are tied to certain benefits, such as free school meals and some extended childcare services. The NRPF restriction affects undocumented migrants as well as most migrants with temporary leave to remain in the UK.

The organisation I work for, Project 17, specialises in working with migrant families with NRPF, primarily by supporting them to access support from social services. We see the destitution enforced by the NRPF restriction on families across England on a daily basis. Experiences of street homelessness, hunger, debt, exploitation, and domestic abuse are all too common. Black and Asian working-class women and children are disproportionately impacted by NRPF. Like other organisations supporting those with NRPF (Woolley, 2019), Project 17 works predominantly with black women from countries formerly colonised by the British Empire. Most are single mothers, often in low-paid employment such as care work - which has also been made more visible by Covid-19and catering. If they are undocumented, they may be working informally and without legal protections. Alongside work, mothers with NRPF will be managing the demands of childcare, and during the pandemic, the difficulties of home schooling, generally without access to the internet or laptops/computers. Having no access to welfare support forces these women to work long hours, often in poor conditions, in an attempt to meet their and their children's needs. Nonetheless, it is usually impossible for them to do so. The NRPF condition makes their labour more exploitable and, with high immigration fees and little to live on, often pushes them into debt. They are therefore rendered prime sources of exploitation for employers and of profit for loan-sharks. At the same time, immigration controls on welfare work to ensure that negatively racialised migrants from former British colonies are denied access to the 'spoils' of Empire (El-Enany, 2020). The enforced destitution experienced by these families as a result of the immigration system can therefore be understood as a process of subordination and exclusion that perpetuates the violence of colonialism.

Destitute families with NRPF often find themselves caught between the UK's migration policies and local authority statutory duties towards safeguarding children. It has been argued that under section 17 of the Children Act 1989, local authorities effectively administer a 'parallel welfare system' (Price and Spencer, 2015) to families with NRPF. This legislation imposes a statutory duty on local authorities to safeguard and promote the welfare of 'children in need' in their area. However, support 
is notoriously difficult to access, and has become even harder to obtain since the pandemic. One in six families Project 17 works with are wrongly refused assistance by local authorities when they first seek support. With austerity, welfare retrenchment, and the recent pressures of Covid-19, local authority 'gatekeeping' strategies have multiplied. The families accessing Project 17 report experiencing a culture of hostility and suspicion when accessing local authority NRPF services, encountering a range of methods used to deter them from seeking support. These include threats to take children into care and exhausting and intrusive interview processes. Ade ${ }^{\mathrm{ii}}$, a mother who worked with Project 17 told us, 'they have this way of making you feel less than human.' Our experience is that assessments typically focus on parents' 'credibility' rather than families' material needs. Even if families are able to secure support, the support provided is often inadequate. In many cases, accommodation is far away from children's schools and networks or is overcrowded - for example, one family we supported involved a young child, teenager and their mother given just one room with a bed to share. Additionally, financial support may be as little as $£ 1.70$ a day per person. Lola, an undocumented woman whom I interviewed for my research into the impact of NRPF on families ${ }^{\mathrm{iii}}$, and her son Sultan (age 10) had been given a single room in a $\mathrm{B} \& \mathrm{~B}$ and just $£ 35$ per week between them. They had to pay to use the washing machine in the building and had no access to cooking facilities, except for a small microwave. Lola told me that the social worker had made it clear that the financial support was for her son, but not for her: 'They said they don't have a duty of care to me really, it's just Sultan. How I look after myself is none of their business.' Her life, and the care she provided for her son, were treated as though they did not matter.

While Sultan and other young people precariously positioned by the NRPF policy are some of the poorest children in the UK, they are not ordinarily eligible for free school meals. Prior to the coronavirus outbreak, children whose parents had NRPF were ineligible for free school meals beyond their third year of primary school. This form of 'everyday bordering' left many children hungry and often resulted in families accruing large debts. One child we worked with developed Pica, an eating disorder that meant that he ate non-food items such as plasterboard and fibre from his clothes. He told his mum that the main reason he was eating these things was because he was so hungry, and the family's limited access to food made it difficult for him to stop. For Jade, a young person I interviewed, the fact that her mum had NRPF meant regularly skipping lunch: 'I don't get free school meals. My mum has to pay for my meals but sometimes I don't eat lunch because, like, she needs to get money. Sometimes my belly will just hurt' (Dickson, 2019). Other children I spoke to said they felt stigmatised, ashamed and socially isolated by their exclusion from free school meals.

\section{Borders, the school canteen and Covid-19}

The Covid-19 pandemic has intensified the issues experienced by people with NRPF. Many who were previously managing to get by have found themselves destitute as a result of loss of employment and decreased support from friends and family. This, in addition to public health concerns, has led to increasing public debate about NRPF, including calls from politicians, local government and advocates for a suspension of the condition. A suspension of the policy, however, will do no more than defer migrant destitution. The Covid-19 crisis compounds an already-existing crisis faced by those with NRPF.

The temporary expansion of eligibility for free school meals support, though not a substitute for the abolition of NRPF, will make a palpable material difference to the lives of these families. However, many children in families with NRPF are still not accessing free school meals. The change and entitlement are little known and have been poorly publicised. The policy has also undergone several revisions, which has led to confusion among parents, schools, and NGOs. The financial eligibility criteria have been changed twice, in response to further threats of legal action. Alongside this, the government has amended the length of time for which families will be eligible. Originally, the extension was in place until schools were open to all children, but it has subsequently been extended 
pending the outcome of a government review. The multiple changes and the government's failure to update publicly available information in a timely way has created significant uncertainty about who can and cannot access free school meals.

Unlike most families who apply through a national system, families with NRPF are assessed for free school meals at a local level. Schools and local authorities are thus positioned as free school meals border guards tasked with determining eligibility. Complex immigration legislation combined with widespread lack of knowledge about migration status has led to some children being wrongly refused.

Even during the Covid-19 extension of the school meals policy, many families with NRPF remain ineligible for free school meals. The extension only applies to children whose parents have certain types of legal status - those with leave to remain on private and family grounds under Article 8 of the European Convention on Human Rights and 'Zambrano' carers (non-EEA national primary carers of British children) - or who are in statutory support (e.g. under the Children Act 1989 or asylum support). It does not apply to undocumented families not receiving any statutory support, who are likely to be experiencing the most extreme forms of hardship. These families' lives will have been made even harder by the pandemic.

School canteens remain highly bordered spaces in the time of Covid-19. The immigration status of parents continues to determine which children are included and which are excluded from free school meals, which in turn dictates whether some children eat lunch or go hungry. For those temporarily eligible for free school meals, immigration checks by schools and local authorities have become the prerequisite to access to food. The exact contours of the borders in school canteens may shift again if free school meals support is withdrawn from temporarily eligible families. Whether or not the temporary extension of free school meals is made permanent - something currently being pushed for by families, lawyers, NGOs and activists - it's important to recognise that a change in free school meals policy is not an end in itself. The school canteen is a single site of contestation within a much broader border regime that urgently needs to be challenged and resisted.

This work was supported by the Joseph Rowntree Charitable Trust under a Rights and Justice grant [number 31.19.o].

\footnotetext{
${ }^{\mathrm{i}}$ The no recourse to public funds (NRPF) condition restricts access to mainstream welfare benefits and local authority homelessness assistance. It applies to most migrants on temporary visas and undocumented migrants.

ii All individual names used in this text are pseudonyms for the purposes of anonymity.

iii This research was conducted for Project 17.
} 


\section{References}

Dickson, E. (2019) Not Seen, Not Heard: Children's Experiences of the Hostile Environment London: Project 17

El-Enany, N. (2020) (B)ordering Britain: Law, Race and Empire Manchester: Manchester University Press

Home Office. (2020) No recourse to public funds (NRPF),

https://homeofficemedia.blog.gov.uk/2020/05/05/no-recourse-to-public-funds-nrpf/.

Price, J. and Spencer, S. (2015) Safeguarding children from destitution: Local authority responses to families with 'no recourse to public funds' Oxford: University of Oxford

Woolley, A. (2019) Access Denied: The Cost of the 'No Recourse to Public Funds' Policy London: The Unity Project 